\title{
Online News Frame Comparison about Polemic of RuangGuru as Pre-Work Card Partner
}

\author{
Cosmas Gatot Haryono ${ }^{1}$, Rustono Farady Marta $^{2}$, Maichel Chinmi ${ }^{3}$ \\ Universitas Bunda Mulia, Jln. Lodan Raya No. 2, North Jakarta, 14430, Jakarta, Indonesia ${ }^{1,2}$. \\ Universitas Bunda Mulia, Jalur Sutera Barat Kav. 7-9, Tangerang, 15143, Banten, Indonesia ${ }^{3}$ \\ cgharyono@gmail.com¹,rmarta@bundamulia.ac.id², mchinmi@bundamulia.ac.id ${ }^{3}$
}

\begin{abstract}
This study aims to see how the framing of online news in reporting the polemic of the direct appointment of RuangGuru as a Pre-Work Card partner launched by the government during COVID-19 pandemic. Researchers used qualitative research and Robert N. Entman framing analysis. While the online news which researchers chose as research objects were Kompas.com and Detik.com for comparison. The results show that there are different points of view between the two media in viewing the case. Kompas.com tends to protect and support RuangGuru and the government, while Detik.com, on the other hand, seems to be in opposition to attacking RuangGuru and the government, indirectly.
\end{abstract}

Keywords: Comparison, Framing, Online News, Pre-Work Card, and RuangGuru

\section{Introduction}

During the COVID-19 pandemic whacked Indonesia, Indonesia's education world totally changed, i.e. it changed to online learning model [1]. All students and teachers need to adapt from onsite learning to online learning. For sure, this has a tremendous impact. Not only on the student but also teachers. Outside the parties involved in the teaching process, there is an equally important part, the learning platform. On online there are several learning platforms options that can be used both free and subscribed; both from other countries or local. One of the digital education platforms from Indonesia is RuangGuru.

The existence of RuangGuru gives a new color in sector of education in Indonesia. RuangGuru operates a learning management system that can be used by students and teachers to manage learning activities in the classroom, virtually. Through thousands of questions where the contents are adjusted to the applicable curriculum in Indonesia, RuangGuru provides a new learning model to the Indonesian people. Thus, education can reach all parts of Indonesia. This is in line with the objectives of the Sustainable Development Goals (SDGs), which are the fourth goal, to create quality education. Guaranteed equitable quality education and increased learning opportunities for everyone [2]

As a local platform, RuangGuru was certainly welcomed quite enthusiastically by some elements of the community. Even during the COVID-19 pandemic, RuangGuru was shown as a digital training platform along with Program Kartu Pra-kerja (the pre-employment card program) along with seven other platforms (Tokopedia, Bukalapak, MauBelajarApa, HarukaEdu, PijarMahir, Sekolah.mu, and Sisnaker). However, there are controversial issues which accompany the development of the use of RuangGuru. There are a group to support, but also there are a group who criticizes quite sharply. However it is important to provide application online nowadays [3]. 
Kartu Pra-kerja is a card that is put up in the framework of training and training programs for Indonesian citizens who do not yet have skills. The card was promoted by Joko Widodo during the 2019 Indonesian Presidential Election campaign, along with the KIP Lecture and cheap food packages [4]. Requirements for being able to register for a pre-employment card are Indonesian citizens (WNI) aged 18 years and over and not currently attending school or college. Those who have worked and become victims of layoffs may also register even though the program is prioritized for young unemployed.

The news regarding the direct appointment of eight digital platforms as the partner of the Pre-employment Card program turned out to be part of a "splitting up of media views" in Indonesia. This can be seen from how the media presents their news and managing their risks [5]. How they construct messages, highlight certain aspects while silencing other aspects, create titles and who are the actors or speakers communicate of the news structure that they compile [6]; describe how the media view of the problem that occurs.

The existence of mass media and technology play a very important role [7] in a polemic. The mass media directly or indirectly has a role in constructing the facts which occur [8]. Each media has its own perspective in constructing the facts. The media has the "power" to build a structure of storytelling that leads the readers' meaning. Media itself is never neutral. They have an agenda that is always related to the ideology of their company [9]. Therefore, researchers are interested to see how the mass media construct facts related to the RuangGuru.

Researchers try to look at two popular Indonesian news portals, namely Kompas.com and Detik.com. As two media that have big names in Indonesia, researchers want to capture how news construction is built by each editor. Researchers use framing analysis as a tool to analyse. Framing analysis is often regarded as the basis of cognitive structures that guide the perception and representation of reality [10]. According to Panuju [11], framing analysis is an analysis that tries to dismantle the ideology behind writing information. Framing analysis is used to dissect ways or ideologies of the media when constructing facts. To find out how the role of media ideology in constructing facts, researchers need to examine the strategy of selection, prominence, and linking facts into the news so that it is more meaningful, more interesting, more meaningful or more memorable, to accompany public interpretations according to their perspectives [12].

The researchers used Robert Entman's framing analysis which sees framing as a media act to place information in a specific context, thus, certain issues get a greater allocation than other issues [13]. Framing Entman also places more emphasis on how the communication text is displayed and which parts are highlighted or considered important by the text creator. Thus, an idea or information is more easily seen, more easily noticed, remembered, and interpreted because it is related to the point of view scheme of the audience. So, to analyze the media, Entman proposes that researchers try to describe the selection process and highlight certain aspects of reality built by the mass media.

Robert N. Entman explains framing analysis in two large dimensions, namely as follows: a) Issue selection, namely the researcher's activities look at the choice of themes or issues displayed by the media; b) Emphasis or highlighting certain aspects of reality or issues. In this dimension, researchers look at how the choice of words, sentences, images, and certain images made by to be displayed to the audience.

To conduct a framing analysis of media texts, according to Entman, researchers must go through four important stages, namely [14]:

a. Defining the problem (define problem). The researcher looks at how the media sees an issue or event and identifies how the media places the issue or event in their reporting. This includes seeing what the "problem" makes by the media; 
b. Estimating the problem or source of the problem (diagnose cause). After the researcher observes how the media sees the event, the researcher then diagnoses who is considered to be the cause of a problem;

c. Make moral decisions (make moral judgments). At this stage the researcher must find what moral values are presented to explain the problem and what moral values are used to express an action;

d. Emphasize completion (treatment recommendation). At this stage the researcher tries to analyze the completion of the solution as it is offered to resolve the problem or issue. Is there a "road" that is offered and must be taken to overcome the problem.

\section{Method}

This study uses qualitative research methods in the interpretive paradigm. The researchers use qualitative in this study. Qualitative research is a concept that all entities simultaneously influence each other [15]. Qualitative research is interpretative research (using interpretation) which involves many methods in analyzing research problems [1]. The analysis method used is Robert N. Entman's framing analysis.

\section{Result and Discussion}

In framing the news about the polemic of the appointment of RuangGuru and seven other digital platforms by the government, the two media (Kompas.com and Detik.com) have a different perspective. To see the issue, use the Entman framing analysis framework, Kompas.com tends to "defend" the government; while Detik.com tends to 'attack'.

When the polemic occurred, Kompas.com presented Minister of Finance Sri Mulyani to explain the actual case. The article entitled " Sri Mulyani Singgung Alasan Penunjukan RuangGuru dkk Tanpa Tender" (Sri Mulyani Touched the Reason for Appointment of RuangGuru et al Without Tender), the Kompas.com clearly shows how the mechanism has been carried out correctly by the Government. No mechanism was violated in the direct appointment of eight digital platforms for online training in Program Kartu Pra-kerja (the pre-employment card program) conducted by the government.

It appears that kompas.com is trying to present the problem by giving a clear picture of what is permissible. Through the prominent Sri Mulyani, Kompas.com seemed to 'protect' the government and RuangGuru from the efforts of groups who wanted to exploit the situation for political purposes. By displaying a quote that the eight platforms are not online training providers but only connectors, kompas.com is blocking the protests of some people with the real reality. This was further strengthened by the statement that even if it remained a problem, the online training itself was not included in the category of procurement of goods or services of government agencies so that it did not need to go through a tender mechanism or direct appointment could be made. This is actually part of Kompas.com's indirect assessment that there is nothing wrong with the government policy. Emphasis on the name of Sri Mulyani in the title section, implicitly also shows that Kompas.com is the connecting voice of the government of Sri Mulyani. As if Kompas.com agreed to what was said by Sri Mulyani. 
Table 1. Framing of "Sri Mulyani Singgung Alasan Penunjukan RuangGuru dkk Tanpa Tender" [16]

\begin{tabular}{ll}
\hline Framing Device & \multicolumn{1}{c}{ Findings } \\
\hline Define Problem & $\begin{array}{l}\text { The existence of RuangGuru and } 7 \text { other online platforms on the 2020 } \\
\text { Prakarsa Card has been raised by the public because it has not gone } \\
\text { through a tender process }\end{array}$ \\
The government (through the Minister of Finance, Sri Mulyani) did not \\
conduct the auction process because indeed the 8 online platforms \\
were not online training providers, but only became a liaison between \\
participants and online course providers.
\end{tabular}

The same thing was actually done by Kompas when reporting about protests from several parties who thought that RuangGuru was considered to be a competitor for independent tutoring that was mostly done by the teachers at their leisure time. In that case, Kompas.com also appeared to provide support to RuangGuru. With the title "Considered Disrupting Bimbel Teachers' Business, This Is the Response of RuangGuru Founders" (Dianggap Mendisrupsi Bisnis Guru Bimbel, Ini Respon Pendiri RuangGuru), Kompas.com on April 26, 2020 tried to explain the existing problems. From the chosen title, Kompas.com seems to show that RuangGuru disrupts the tutoring business as a matter of courses. It never happened or just wishful thinking. Problems usually related to majority group who may feel desolated [17] .

Table 2. Framing of "Dianggap Mendisrupsi Bisnis Guru Bimbel, Ini Respon Pendiri RuangGuru” [18]

\begin{tabular}{|c|c|}
\hline Framing Device & Findings \\
\hline Defin & $\begin{array}{l}\text { The assessment that the RuangGuru is a competitor to many tutoring and } \\
\text { tutoring efforts is incorrect }\end{array}$ \\
\hline Diagn & $\begin{array}{l}\text { The development of internet and digital technology is driving the shift in } \\
\text { ways of learning. RuangGuru are seen as actors who can encourage } \\
\text { changes in the learning system in Indonesia }\end{array}$ \\
\hline $\begin{array}{l}\text { Make } \\
\text { Judg }\end{array}$ & $\begin{array}{l}\text { The RuangGuru platform is complementary, and it is precisely that from } \\
\text { the RuangGuru user profile, the majority of RuangGuru users have never } \\
\text { been tutored in their entire lives. }\end{array}$ \\
\hline & $\begin{array}{l}\text { RuangGuru is a technology company in Indonesia that focuses on } \\
\text { education-based services and develops various technology-based learning } \\
\text { services, including virtual classroom services }\end{array}$ \\
\hline ndation & $\begin{array}{l}\text { The presence of RuangGuru is expected to facilitate the community in } \\
\text { obtaining additional education outside of school hours without the need to } \\
\text { think about time boundaries, places, or traffic congestion that is common in } \\
\text { big cities in the country. }\end{array}$ \\
\hline
\end{tabular}

In the article Kompas.com clearly shows its support for the RuangGuru digital platform by displaying the advantages RuangGuru has. Kompas.com considers that the notion of RuangGuru as a competitor to the business of tutoring is inappropriate because the platform is actually just a complement. Even Kompas.com also quoted a resource person (one of RuangGuru's managers) that the majority of RuangGuru users have never attended tutoring for 
their whole life. This quote is contradictory to the claims of several parties who have been protesting against RuangGuru.

Even Kompas.com sees RuangGuru as an important actor in driving changes in the learning system in Indonesia to virtual. Through technology, RuangGuru is considered a party capable of developing IT technology-based learning systems and virtual classroom services. Do not stop there, Kompas.com also praised RuangGuru for facilitating the community in obtaining additional education outside of official study hours without the need to think about time limits, places, or traffic jams.

Kompas.com's position in the two polemics seemed pro or in support of the government and RuangGuru. As part of the Kompas Group media group, Kompas.com seems to continue or be in harmony with the style of Kompas print reporting, which so far has been more progovernment policies. Even if it gives criticism, Kompas never gives a frontal criticism, but with subtle criticism.

Meanwhile, Detik.com shows the opposite when there was a polemic regarding the direct appointment of RuangGuru and seven other digital platforms. Detik.com emphasizes those who are counter to the government policy. In an article titled "KPPU Bakal Periksa Keterlibatan RuangGuru cs di Kartu Pra Kerja" (KPPU Will Check the Involvement of RuangGuru cs on the Pre-Work Card) on Thursday, April 23, 2020, Detik.com highlighted the importance of government openness and demands for an open tender in determining the partners of the Pre-Employment card program.

The actual chosen title in plain view indicates Detik.com's position in the polemic. Detik.com highlights the attitude of the KPPU who will conduct an examination of the direct appointment process. KPPU or The Business Competition Supervisory Commission is an independent institution in Indonesia established to oversee the implementation of Law no. 5 of 1999 concerning Prohibition of Monopolistic Practices and Unfair Business Competition.

Table 3. Framing of "KPPU Bakal Periksa Keterlibatan RuangGuru cs di Kartu Pra Kerja" [19]

\begin{tabular}{ll}
\hline Framing Device & \multicolumn{1}{c}{ Findings } \\
\hline Define Problem & $\begin{array}{l}\text { The Business Competition Supervisory Commission (KPPU) said it would } \\
\text { examine the process of involving RuangGuru with } 7 \text { other digital platform } \\
\text { partners who were invited by the government to implement the Pre-Work } \\
\text { Card program. This step was taken because the process of selecting the } 8\end{array}$ \\
partners is still a polemic in the community. \\
Direct appointment of RuangGuru cs as partners is considered to violate the \\
rules because it is not through a tender and is not open to the public. \\
Actors involved: KPPU Commissioner Guntur Saragih and KPPU Director of \\
Competition and Partnership Advocacy Abdul Hakim Pasaribu
\end{tabular}

In the article Detik.com clearly shows its support for those who attacked the government over the policy of direct appointment of RuangGuru and seven other digital platforms as partners of the Work Forces program. Detik.com emphasizes some of the arguments from those who are counter to the policy.

The direct appointment of RuangGuru cs as partners of the Workers' Card program was deemed inappropriate and not in accordance with the principles of fair business competition. 
The determination of partners for the Workers Card program should be carried out through an open tender because after all the program uses state funds which are also public money. Even Detik.com shows the amount of money the government spent on the program, which is $\mathrm{Rp} 20$ trillion.

Detik.com does not display RuangGuru or seven other digital platforms at all. Thus, Detik.com did not cover both sides of the case. As if Detik.com wants to say that this program is important because from the beginning the procedure was wrong, so there are concerns that certain interests will play in the capture. But unfortunately, Detik.com does not do further clarification and verification to related parties, including the government. Considering this issue can have wide-ranging impact, Detik.com should carry out an important journalistic principle, which is verification of the overall data. As a big media, it's a shame it wasn't done.

The same thing was done by Detik.com when there was a polemic regarding the certification issued by RuangGuru. At the end of April 2020 there was a Senior Journalist (Agustinus Edy Kristyanto) who protested against RuangGuru's certification related to journalism training which did not involve credible institutions in the world of journalism such as Dewan Pers (the Press Council), Lembaga Pers Dr. Soetomo (the Press Institute Dr. Soetomo - LPDS), or Lembaga Penelitian Pendidikan dan Penerbitan Yogyakarta (Yogyakarta Research and Publishing Research Institute - LP3Y).

In one day (30 April 2020) Detik.com published news from both parties (Agus and RuangGuru) separately, but interestingly, the next day (1 May 2020 ), Detik.com returned the news under the title "Kejanggalan Kartu Pra Kerja Dibongkar, Ini Jawaban Anak Buah Belva” (Discrepancy Pre-Work Card Dismantled, This is Belva's Answer). With such a title, it should be the most important or the headline should be Belva's answer. But that is not the case. Precisely what was shown earlier (page 1) was Agus Edy Krityanto's statement about RuangGuru's incompetence.

Table. 4 Framing of "Kejanggalan Kartu Pra Kerja Dibongkar, Ini Jawaban Anak Buah Belva" [20]

\begin{tabular}{ll}
\hline \multicolumn{1}{c}{ Framing Device } & \multicolumn{1}{c}{ Findings } \\
\hline Define Problem & $\begin{array}{l}\text { RuangGuru issued a Journalisitk certificate not from a competent party in } \\
\text { the world of the press, such as the Press Council, the Press Institute Dr. } \\
\text { Soetomo (LPDS), or Yogyakarta Educational and Publishing Research }\end{array}$ \\
& $\begin{array}{l}\text { Institute (LP3Y) } \\
\text { RuangGuru is considered not professional in conducting training because it } \\
\text { is considered not to involve more professional parties. While the }\end{array}$ \\
& $\begin{array}{l}\text { RuangGuru responds by stating that the writer (Augustine) Tendentious in } \\
\text { his writings. } \\
\text { There is the inclusion of the name Belva (CEO RuangGuru) in the headline }\end{array}$ \\
Make Moral & RuangGuru does not open until attempts at the discord of irregularities \\
occur & \\
Treatment & -
\end{tabular}

Deliberately or not, Detik.com swapped positions for important matters in the news. By emphasizing the irregularities revealed at the beginning of the news, it shows Detik.com's position in the case, which is in favor of Agus Edy Kristyanto. As if the answer or clarification from RuangGuru is not too important so it is placed on the back. Even though the most important thing to be reported was the answer from RuangGuru. When examined in depth, the title created by Detik is actually a form of justification or assessment. The sentence "Kejanggalan Kartu Pra Kerja Dibongkar..." (Discrepancy Pre-Work Card Disassembled ...) 
is a form of sentence assessment that there has been an odd practice. The media should not judge before a court decision.

From the Entmat framing above, it is clear how the two media have different points of view in constructing news related to the direct appointment of RuangGuru and seven other online platforms as partners of the Pre-employment Card Program. Detik.com tends to present problems straightforwardly and tends to 'show mistakes' made by both the government and RuangGuru. The title selection was done tendently and highlighted the negative side of the government policy. Things that look bad and negative are displayed as headlines, while clarification or rebuttal from the government or RuangGuru tends to be displayed on the back or in other words are placed on the unimportant parts. In the news with the title 'Kejanggalan Kartu Pra Kerja Dibongkar, Ini Jawaban Anak Buah', it seems clear. In the headline section it was filled with protests from Agustinus Edy Kristyanto, while Belva's answer was placed in the next section which (in general) was always considered unimportant in the world of journalism. Yet if you see the title, the headline should be the answer from Belva's men.

Whereas kompas.com tends to display news 'safely' for the government. Kompas.com seems to provide support and tend to 'protect' the government and RuangGuru related to the policy. Kompas.com does not give a negative impression of the government policy. The article published by Kompas.con actually seemed to give the government a chance to clarify the polemic that occurred. Even in the article entitled 'Sri Mulyani Singgung Alasan Penunjukan RuangGuru dkk Tanpa Tender', Kompas.com seemed to position itself as a mouthpiece of the government represented by Minister of Finance Sri Mulyani.

When reviewing what Robert Entman [13] has said, that the media often display certain texts or highlight certain aspects by giving more and in-depth attention so that they are easier to see, easier to notice, remember, and interpret, Detik.com editorial teams tends highlighting the mistakes and weaknesses of government policy so that it attracts public attention. They prefers titles that are sensational and preferred by the public, especially those who do not like the current government. Cover the news with a title that 'slaps' the government Thus, detik.com can attract the interest of people who do not agree with these policies to read the article. And actually this illustrates who is behind Detik.com, namely a businessman who is also a former Minister in the era of President SBY, Chairul Tanjung. On the contrary, Kompas.com tends to display news from the government side. So far, Kompas group is known to be quite careful in reporting matters related to government policies. Aside from not chasing sensational matters, Kompas always plays 'safe' in reporting news. Even if giving criticism is never done in a 'rough'.

\section{Conclusion}

Based on the analysis conducted by researchers, it can be concluded that the two online news (Kompas.com and Detik.com) have different points of view in seeing the RuangGuru polemic. Kompas.com tends to support the government and RuangGuru related to the emerging polemic. Even Kompas.com does not hesitate to show its support through titles that directly describe support for the government. Conversely, Detik.com tends not to support the government or RuangGuru. Detik.com took a position opposite the government and criticized many government policies and RuangGuru.

Researchers suggest that the media be wiser in reporting information, not just "attacking" RuangGuru. Even though the media has the freedom to report information, it should keep the 
journalistic code of ethics in good hands, especially related to data verification. In addition, by applying a good journalistic code of ethics, the media can also support the achievement of the fourth SDGs goal, which is quality education.

\section{References}

[1] R. F. Marta, A. A. Prasetya, B. Laurensia, and K. L. Syarnubi, "Imbalance Identity in E-Sports News Intersectionality on Covid-19 Pandemic Situation," J. ASPIKOM, vol. 5, no. 2, p. 207, 2020 .

[2] Editor, "Sosialisasi Rencana Aksi Nasional (RAN) Tujuan Pembangunan Berkelanjutan (TPB/SDGs) 2017-2019," bappenas.go.id, 2018. http://sdgs.bappenas.go.id/sosialisasi-rencanaaksi-nasional-ran-tujuan-pembangunan-berkelanjutan-tpbsdgs-2017-2019/ (accessed Jul. 28, 2020).

[3] R. Rahim, E. F. Armay, D. Susilo, R. F. Marta, and A. Alanda, "Cloud computing security issues and possibilities," Int. J. Eng. Adv. Technol., vol. 8, no. 6 Special Issue, pp. 927-931, 2019, doi: 10.35940/ijeat.F1175.0886S19.

[4] J. A. Sagita, "Cara Jokowi Promosikan 3 Kartu Pra Kerja Saat Kampanye di Banyuwangi: Hayo Siapa yang Nggak Setuju?,” tribunnews.com, 2020. https://www.tribunnews.com/pilpres2019/2019/03/25/cara-jokowi-promosikan-3-kartu-pra-kerja-saat-kampanye-di-banyuwangihayo-siapa-yang-nggak-setuju (accessed Jul. 28, 2020).

[5] R. F. Marta, G. S. Achmad Daengs, A. Daniar, W. O. Seprina, and A. P. Menayang, "Information security risk and management in organizational network," Int. J. Eng. Adv. Technol., vol. 8, no. 6 Special Issue 2, pp. 1152-1156, 2019, doi: 10.35940/ijeat.F1286.0886S219.

[6] K. Simorangkir, R. F. Marta, and T. Sadono, "Student's Participation in Class: Between Proximity, Teaching Method, and Communication Intensity," in The 3rd English Language and Literature International Conference, ELLiC, 27th April 2019, Semarang, Indonesia, 2019, no. 20, doi: 10.4108/eai.27-4-2019.2285486.

[7] R. Farady Marta et al., "Author Compliance in Following Open Journal System of Communication Science in Indonesia," J. Phys. Conf. Ser., vol. 1175, no. 1, p. 3, 2019, doi: 10.1088/1742-6596/1175/1/012222.

[8] M. Chinmi, R. F. Marta, C. G. Haryono, J. Fernando, and Jai Kishon Goswami, "Exploring Online News as Comparative Study Between Vendatu at India And RuangGuru from Indonesia In COVID-19 Pandemic," J. Content, Community Commun., vol. 11, p. 168, 2020, doi: 10.31620/JCCC.06.20/13.

[9] C. G. Haryono, "Praktek Produksi Hegemoni Militer Melalui Film 'Jenderal Soedirman,", Bricol. J. Magister Ilmu Komun., vol. 3, no. 01, p. 30, 2017, doi: 10.30813/bricolage.v3i01.844.

[10] F. K, "Locating Frames in the Discursive Universe ' Goffman and the Sociology of Framing," Sociol. Res., vol. 2, no. 3, pp. 1-31, 2011.

[11] R. Panuju, "Framing Analysis," Makal. Surabaya Univ. dr. Soetomo, vol. 2, p. 115, 2003.

[12] A. Sobur, Analisis Teks Media: Suatu Pengantar untuk Analisis Wacana, Analisis Semiotik, dan Analisis Framing. 2006.

[13] Eriyanto, Analisis Framing: Konstruksi, Ideologi, danPolitik Media. PT Elkis, 2006.

[14] Eriyanto, Analisis Framing: Konstruksi, Ideologi, danPolitik Media. PT Lkis, 2002.

[15] D. Mulyana, Metodologi Penelitian Kualitatif. PT Remaja Rosdakarya, 2010.

[16] Editor, "Sri Mulyani Singgung Alasan Penunjukan RuangGuru dkk Tanpa Tender," kompas.com, 2020. https://money.kompas.com/read/2020/05/09/155311526/sri-mulyani-singgung-alasanpenunjukan-RuangGuru-dkk-tanpa-tender (accessed Jul. 28, 2020).

[17] J. Basyir, R. F. Marta, and Y. B. Setiawan, "Redefining the Relationship of Majority and Minority as a Social Principle," Emerging Trends in Psychology, Law, Communication Studies, Culture, Religion, and Literature in the Global Digital Revolution. p. 60, 2020, doi: 
10.1201/9780429322259-14.

[18] M. Idris, "Dianggap Mendisrupsi Bisnis Guru Bimbel, Ini Respon Pendiri RuangGuru," kompas.com, 2020. https://money.kompas.com/read/2020/04/26/172157326/dianggapmendisrupsi-bisnis-guru-bimbel-ini-respon-pendiri-RuangGuru (accessed Jul. 28, 2020).

[19] S. Novika, "KPPU Bakal Periksa Keterlibatan RuangGuru cs di Kartu Pra Kerja," 2020. https://finance.detik.com/berita-ekonomi-bisnis/d-4988629/kppu-bakal-periksa-keterlibatan-

RuangGuru-cs-di-kartu-pra- (accessed Jul. 28, 2020).

[20] S. Novika, "Kejanggalan Kartu Pra Kerja Dibongkar, Ini Jawaban Anak Buah Belva," detik.com, 2020. https://finance.detik.com/berita-ekonomi-bisnis/d-4998198/kejanggalan-kartu-pra-kerjadibongkar-ini-jawaban-anak-buah-belva? ga=2.188776235.1273423501.1595691900-

1042514297.1595376630 (accessed Jul. 28, 2020). 